\title{
13. EOCENE PORCELLANITES AND EARLY CRETACEOUS CHERTS FROM THE WESTERN NORTH ATLANTIC BASIN
}

\author{
Volkher Riech and Ulrich von Rad, Bundesanstalt für Geowissenschaften und Rohstoffe, (Federal Institute \\ for Geosciences and Natural Resources), D-3000 Hannover 51, West Germany
}

\begin{abstract}
Major results from a petrographic study of porcellanites and cherts are as follows:

1) Acoustic Horizon $A$ consists of isochronous but facies-independent lower to middle Eocene immature porcellanites. A biogenic silica source is inferred. The porous sediments are first cemented and later replaced by opal-CT, producing a dense or lepispheretype fabric. Porcellanites within the clayey environment include silicified (radiolarian) mudstones and turbidite sands rich in sponge spicules. Poorly consolidated Eocene chalks show gradual transitions to calcareous porcellanites, which contrast with the discrete nodules typical of more strongly lithified carbonates.

2) Before chertification, early-diagenetic quartz occurs locally in porcellanites as replacement of foraminifer tests and latest-generation cavity-filling cement.

3) With increasing burial depth and age, radiolarians are transformed in situ from the original opal-A into opal-CT, and finally into quartz. The boundary between sediments containing siliceous fossils preserved as opal-A and as opal-CT coincides with the uppermost porcellanites of each site.

4) The diagenetically mature Lower Cretaceous quartz cherts contain quartz-replaced lepispheres, suggesting a porcellanitic precursor stage. This indicates an age-, temperature-, and facies-controlled maturation process from opal-A to quartz via opal-CT.
\end{abstract}

\section{INTRODUCTION}

A major scientific objective of Leg 43 was to determine the age, nature, and origin of the prominent acoustic Horizon $A$ in the western North Atlantic Basin, and its significance. Whereas the first aspect of that objective could be fulfilled by the results of the drilling and subsequent studies, interpretation of the origin of these isochronous porcellanite and chert occurrences is still highly speculative.

Our study aimed mainly at understanding the lithofacies of the silicified sediments and the different diagenetic steps between primary siliceous oozes, immature porcellanites, and mature quartz cherts (Table 1; Figure 5). We investigated 48 samples, comprising Eocene porcellanites, Lower Cretaceous quartz cherts, and unsilicified sediments rich in siliceous fossils. The petrography and mineralogy were studied by semiquantitative thin-section and scanning electron microscope (SEM) analyses. X-ray diffraction analysis (XRD), kindly provided by Dr. H. Rösch, Hannover, helped to identify and estimate the contents of silica phases and other minerals (Table 2; for methods see von Rad et al., 1978). The mineralogy of isolated siliceous fossils was optically determined.
Our knowledge of the unsilicified original sediments is based mainly on the shipboard report. Only preliminary results are repórted on the characteristic transformations of siliceous fossils in sections above and below the porcellanite Horizon $A$.

\section{DISTRIBUTION OF SILICIFIED SEDIMENTS}

Silicified sediments (porcellanites and quartz cherts) occur at all Leg 43 sites where Eocene (384-387) and Lower Cretaceous sediments (Site 387; see Figure 1) were recovered. Acoustic Horizon $A$ is always formed by the top of the lower to middle Eocene silicified sediments; according to our definition (Table 1), all those rocks are opal-CT rich ${ }^{1}$ porcellanites; that is, they are immature (metastable) products of intermediate diagenesis (Figure 5, Table 2). Mature quartz cherts, interbedded with Lower Cretaceous limestones, were recovered only at Site 387 on the western Bermuda Rise (Figure 1).

The thickness of the intervals containing silicified layers appears to correlate positively with the accumulation rates of the associated host sediments. At Site

\footnotetext{
${ }^{1}$ For definition see Jones and Segnit (1971).
} 
TABLE 1

Classification of Silicified Sediments (modified from von Rad et al., 1978)

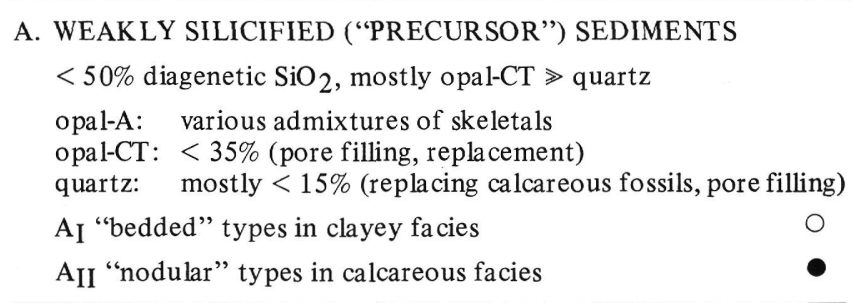

B. PORCELLANITES

$>50 \%$ diagenetic $\mathrm{SiO}_{2}$, opal-CT $\gg$ quartz

opal-A: usually dissolved and/or replaced by opal-CT or quartz $\left.\begin{array}{ll}\text { opal-CT: } & 50 \%-95 \% \\ \text { quartz: } & \text { mostly 5\%-15\% }\end{array}\right\}$ as in A

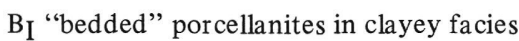

1) hemipelagic

2) pelagic, radiolarian-rich

3) ? hemipelagic, palygorskite-rich

$\Delta$

$\triangle$

BII "nodular" porcellanites in calcareous facies

BIII opal-CT cemented clastic rocks, e.g., turbiditic arenites, conglomerates etc.

\section{C. "MATURE" QUARTZ CHERTS}

$\gg 50 \%$ diagenetic $\mathrm{SiO}_{2}$, quartz $\gg$ opal-CT

$\mathrm{C}_{\mathrm{I}}$ quartz cherts in clayey facies (aged porcellanites $B_{I} 1-3$ )

$\mathrm{C}_{\text {II quartz cherts in calcareous facies }}$ (aged porcellanites $\mathrm{B}_{\mathrm{II}}$ )

Note: Nomenclature of opal-A and opal-CT after Jones and Segnit

(1971). Not all listed types occur in Leg 43 sediments.

384 (northern slope of Sohm Abyssal Plain), thin porcellanite layers interbedded with nannofossil oozes occur only in an interval less than 8 meters thick; at Site 385 (flank of Vogel Seamount), they are concentrated in a 12-meter-thick sequence of radiolarian clays. The two sites on the Bermuda Rise (386 and 387) are characterized by considerably higher accumulation rates. The lower to middle Eocene sediment sequences are 220 to 250 meters thick; and porcellanites occur over vertical intervals of 120 to 140 meters. In the rapidly accumulated Lower Cretaceous limestones of Site 387, chert is scattered over a 170 -meter interval.

The sediments associated with the porcellanites and cherts of Leg 43 are of pelagic to hemipelagic origin. Both the Eocene nannofossil ooze and chalk of Site 384 and the Lower Cretaceous limestone of Site 387 were deposited in a deep-water pelagic environment above (near) the CCD. The porcellanite-bearing Eocene sediments of Site 385,386 , and 387 are represented by hemipelagic silty clays and turbidites which had been deposited on the flank of Vogel Seamount and Bermuda Rise. Before silicification, these bedded porcellanites consisted of silty clays with various amounts of radiolarians; calcareous clays with foraminifers, radiolarians, and sponge spicules; and turbidites rich in fine-grained terrigenous quartz, foraminifers, and sponge spicules (Site 387).
Highly variable proportions of siliceous microfossils are present in all porcellanites or cherts in the clayey, calcareous, and turbidite facies. In some of the siliceous sediments it can be demonstrated that silica has been dissolved, redistributed, and locally reprecipitated in nearby porcellanite beds. However, not all maxima of biogenic opal at the Bermuda Rise Sites 386 and 387 (e.g., the siliceous turbidites) coincide with the major occurrences of porcellanites; diagenetically precipitated silica appears to be lacking in the Upper. Cretaceous claystones of both sites, although the claystones contain a number of radiolarian sands which can be several centimeters thick.

\section{LITHOFACIES OF EOCENE PORCELLANITES}

All the silicified rocks comprising the prominent Eocene reflector sequence (Horizon $A$ ) consist of opalCT-rich porcellanites. They can be conveniently subdivided into bedded porcellanites associated with clayey sediments, silicified turbidites with opal-CT-replaced calcilutitic matrix, and calcareous (nodular) porcellanites (Table 2). Our classification is shown in Table 1 and discussed by von Rad et al. (1978).

\section{Bedded Porcellanites (clayey environments)}

Since the lower to middle Eocene sediments at Site 385,386 , and 387 (Figure 1) are predominantly pelagic and hemipelagic clays deposited below the CCD, only bedded porcellanites (Type BI) and a few silicified turbidites (BIII) are present. They are associated with pelagic radiolarian clays and oozes (Site 385) and with hemipelagic claystones, calcareous claystones, and radiolarian mudstones (Sites 386 and 387). In detail, the lower to middle Eocene of Site 387 consists of a rhythmically bedded mudstone-turbidite series, 190 meters thick, with the following idealized sequence of $\mathrm{cm}$ - to dm-thick subunits (see Site 387 Report, this volume):

$\epsilon$ : dark non-calcareous radiolarian mud with interbedded porcellanites (top).

$\gamma \& \delta$ : radiolarian mud with a down-hole increase of nannofossils.

$\beta$ : thinly laminated radiolarian mud.

$\alpha$ : silty, sandy, sponge spicule-radiolarian mud with a few silicified turbidite beds (base).

\section{Composition (Figure 2:3)}

Among the porcellanites of the clayey environment, only those of Site 387 are rich in terrigenous silt (3 to 10 per cent) and dispersed carbonate (up to 20 per cent undifferentiated fine-grained carbonate, nannofossils, and small foraminifers). The porcellanites of Sites 385 and 386 contain 20 to 40 per cent radiolarians, those from Site 387 only about 5 per cent. Often a few per cent of sponge spicules and glauconite (always associated with foraminifers) are present; this indicates a transitional facies to the silicified turbidites (Figure 2:4).

In comparison with the calcareous porcellanites (Site 384), the bedded porcellanites of Leg 43 have higher opal-CT contents (more than 70 per cent). This may 


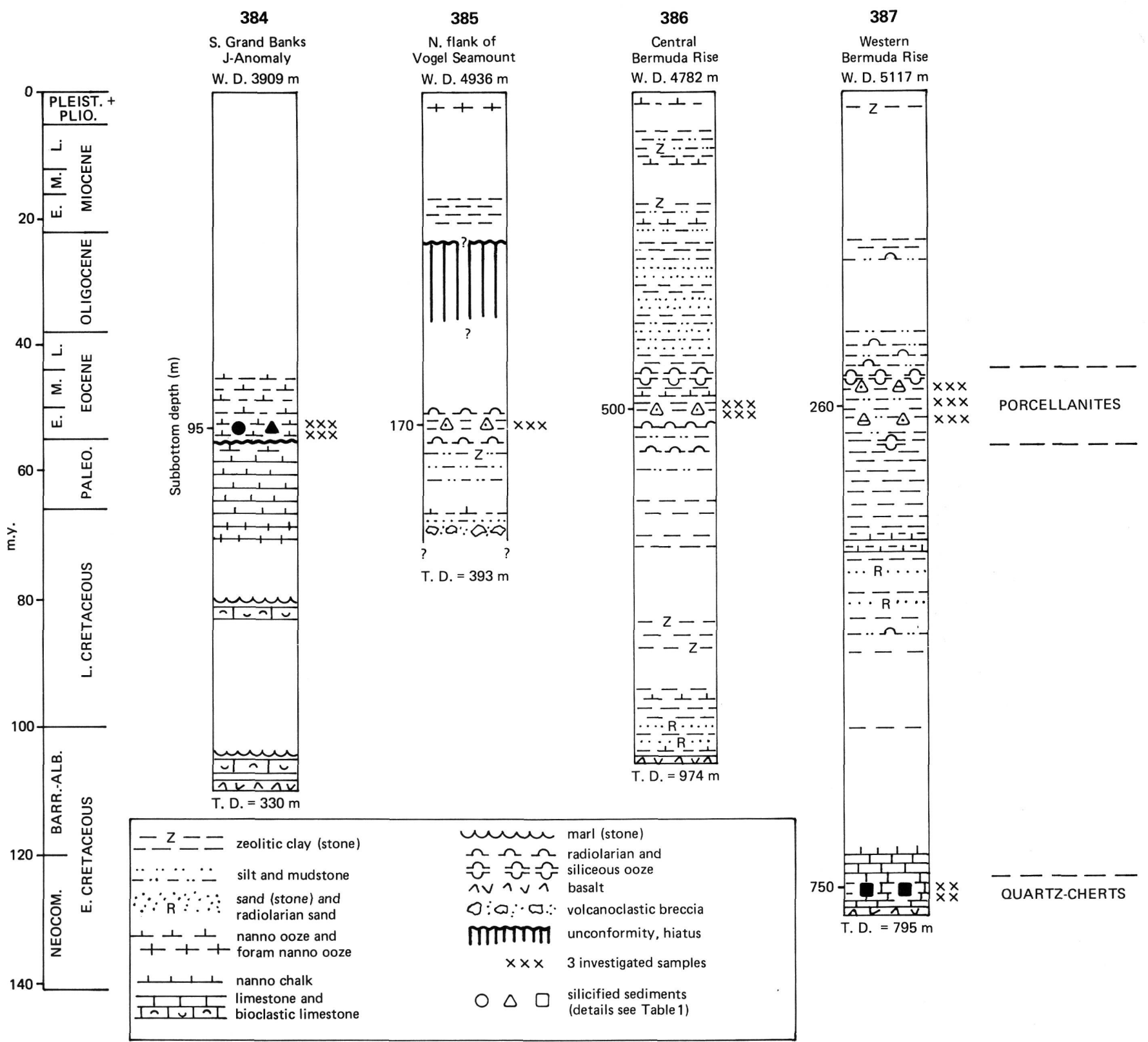

Figure 1. Lithostratigraphy of Sites 384-387, showing age and facies associations of porcellanites and quartz cherts.

be a result of higher original admixtures of biogenic opal in the radiolarian clays, and/or a more advanced diagenetic stage because of deeper burial.

\section{Ultrastructure of the Matrix}

The matrix of both nodular and bedded porcellanites can have either a dense or a lepisphere-type fabric (Plate 1, Figure 1). Under the microscope, only the dense fabric of clayey porcellanites shows a uniform extinction of the total matrix under crossed nicols, if polarizer or analyzer are parallel to the bedding plane (aggregate polarization); that is, isotropic matrix areas with a lepisphere-type fabric alternate with dense matrix zones showing aggregate polarization (Table 3 ).

This means that lepisphere-type fabrics never show aggregate polarization whereas the more common, dense opal-CT matrix is often (but not necessarily) as- sociated with this phenomenon. If compared with the palygorskite-rich ( 5 to 30 per cent) porcellanites from the eastern North Atlantic (Legs 14 and 41; von Rad and Rösch, 1974; von Rad et al., 1978), the aggregate polarization in Leg 43 porcellanites is much less conspicuous and often restricted to single microflasers, patches, or layers.

In the matrix of a few porcellanites with relatively high porosities, the lepisphere-type fabric can be recognized by SEM. Besides well-bladed lepispheres, poorly bladed (stubby or spiny) lepispheres can also be observed (Plate 1, Figure 1). These stubby lepispheres are only evident in bedded porcellanites of the clayey environment (see also Flörke et al., 1976). Diagenetic quartz is missing in many of the clayey porcellanites investigated. In some samples, a late-diagenetic quartz cement has begun to fill part of the remaining 
TABLE 2

Lithofacies, XR-Mineralogy, and Mode of Silicification (thin-section and SEM analysis) of Investigated Leg 43 Porcellanites and Cherts

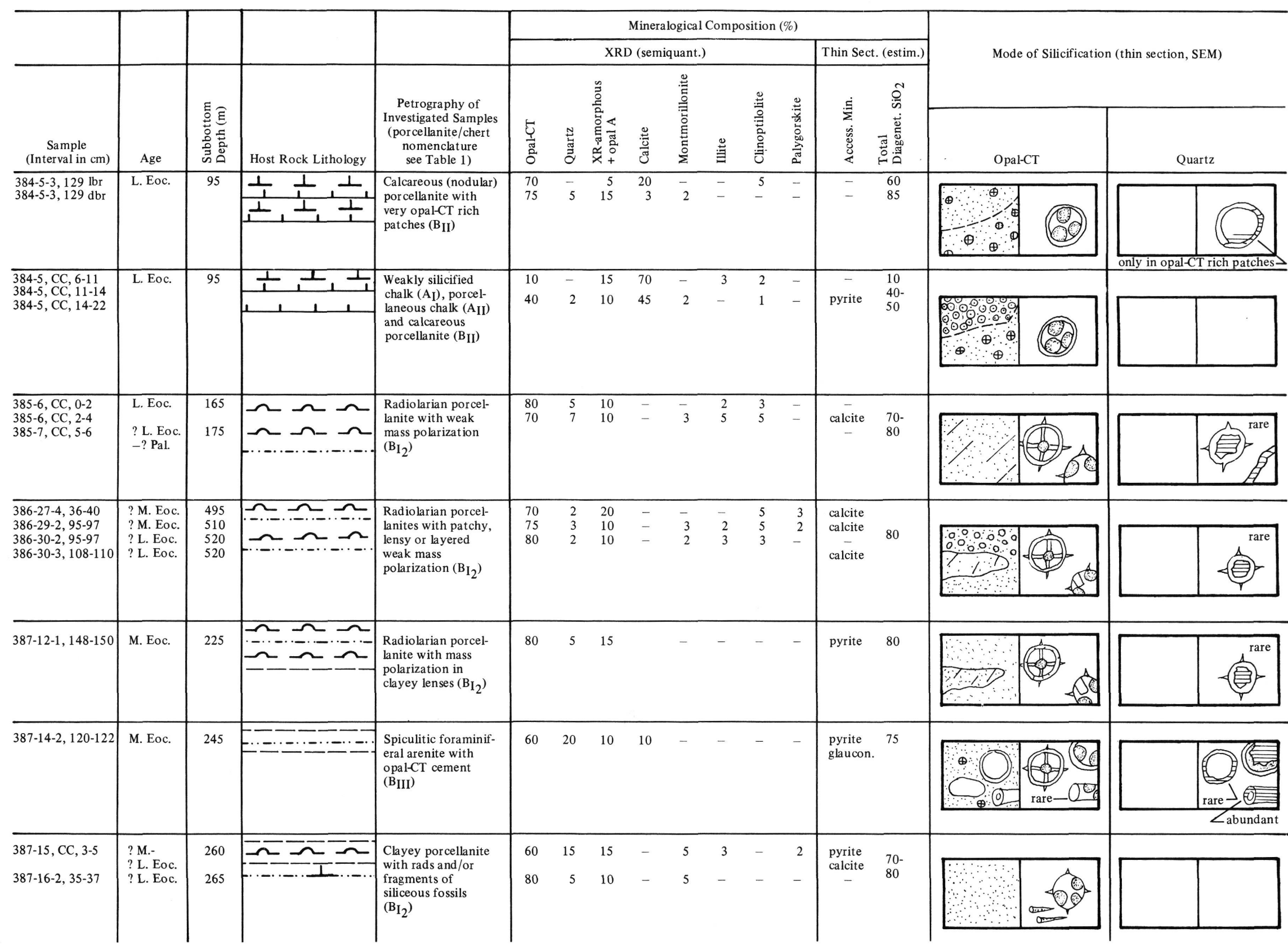




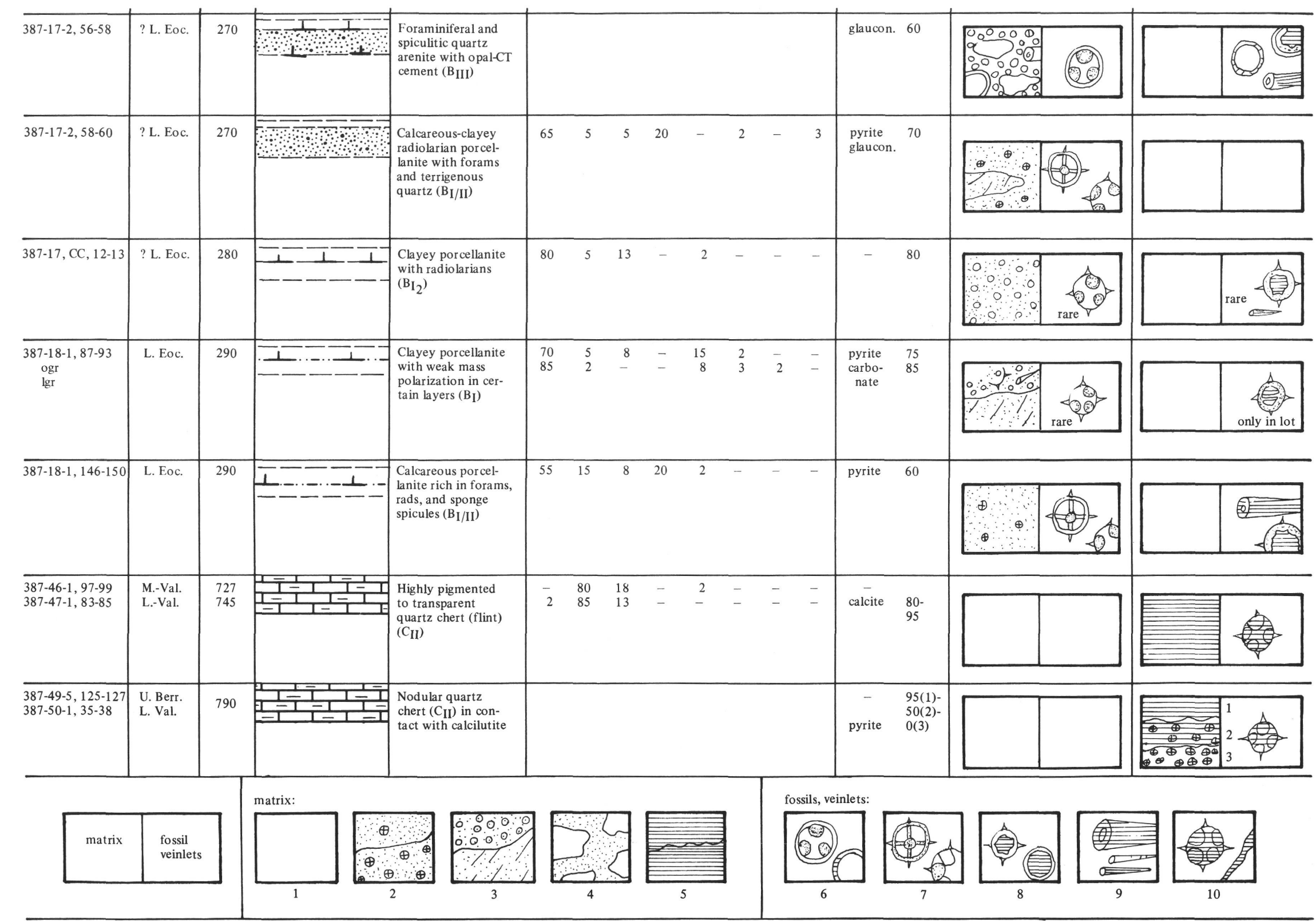

Note: Explanation of symbols: $1=n o$ opal-CT or quartz in matrix: $2=$ (dense) opal-CT matrix with different proportions of carbonate (coccolith symbols): $3 \mathrm{a}=$ opal-CT matrix with lepispheres: $3 b=$ opal-CT/clay matrix with weak aggregate polarization. $4=$ opal-CT cementing an arenite. $\mathrm{Sa}=$ quart matrix, $\mathrm{Sb}=$ quartz matrix with relict carbonate (coccolths): $6=$ foraminifer with opal-CT lepisphere filling (top) or with partly quartz-replaced test (lower right): $7=$ radiolarians with opal-CT replaced skeleton (upper left) or with \pm dissolved skeleton and zeolite + lepisphere
filling: $8=$ quartz-filled radiolarian ghost (top) and foraminifer (below): $9=$ quartz-replaced sponge spicule (top), radiolarian spines with opal-CT (middle) or quartz filling (base): $10=$ quartz$\mathrm{lbr}=$ light brown, $\mathrm{dbr}=$ dark brown, $\mathrm{ogr}=$ olive gray. 


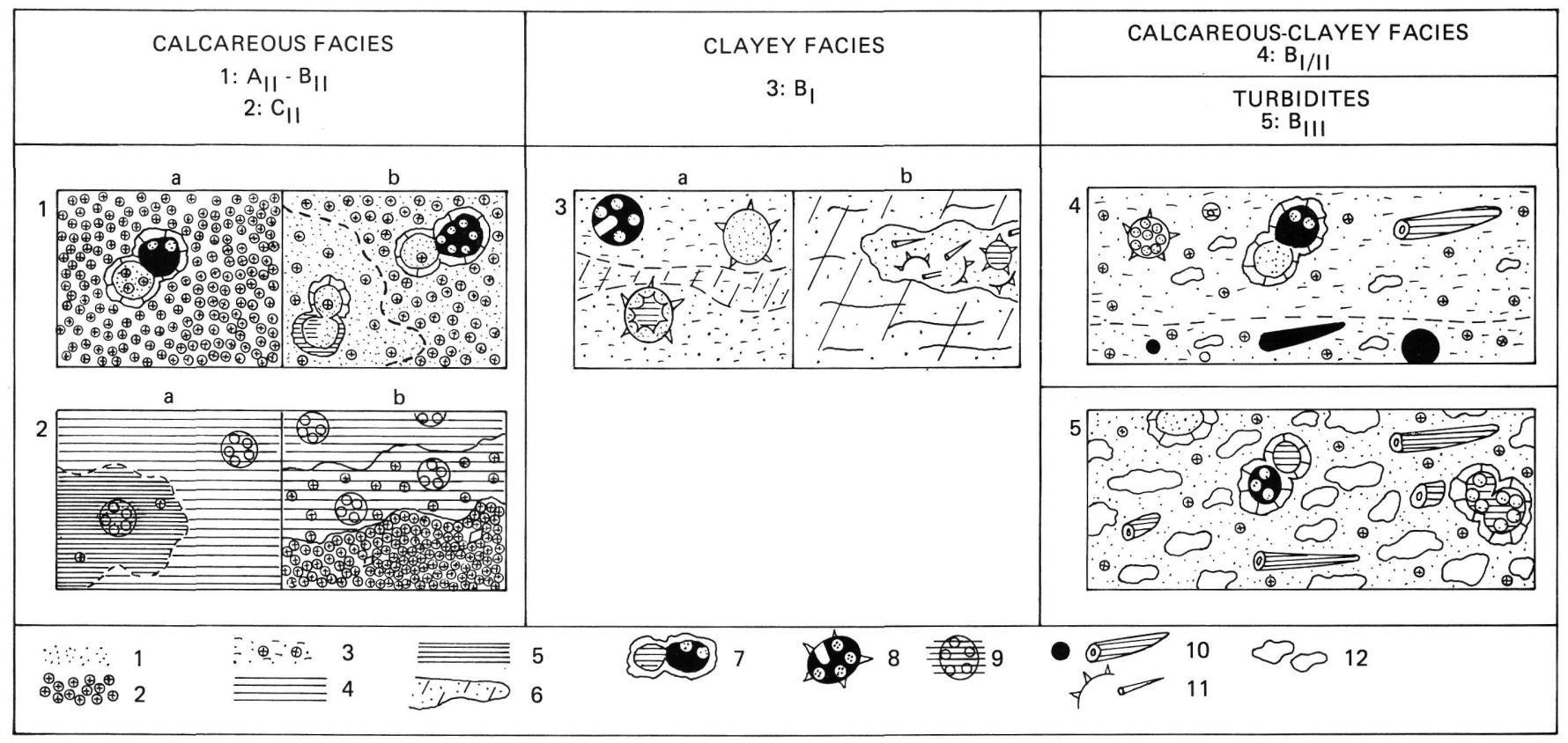

Figure 2. Microfacies of silicified Leg 43 sediments (generalized line drawings after typical thin section or SEM photomicrographs). Detailed explanation in text. Explanation of symbols: $1=$ dense opal-CT; 2 = nannofossil chalk (limestone); 3 = matrix consisting of opal-CT, carbonate, and clay; $4=$ transparent diagenetic quartz; 5 = highly pigmented ("dirty") diagenetic quartz; 6 = area with weak aggregate polarization; $7=$ calcitic foraminifer (left chamber filled by quartz, right chamber empty, with a few opal-CT lepispheres); 8 = radiolarian with recognizable remains of skeleton (interior partly empty, partly filled by zeolite laths and opal-CT lepispheres); 9 = radiolarian ghost filled with quartzreplaced lepispheres; 10 = quartz-replaced sponge spicule with ghost of spicule (left); 11 = remains of siliceous skeletons; 12 = terrigenous quartz grains.

TABLE 3

Characteristics of Opal-CT Fabrics in Sample 387-18-1, $87-93 \mathrm{~cm}$ (trends in abundance indicated by,,,-++++++ ; see also Figures 2,3 )

\begin{tabular}{|c|c|c|}
\hline & $\begin{array}{c}\text { Dense Opal-CT } \\
\text { Fabric }\end{array}$ & $\begin{array}{c}\text { Lepisphere-Type } \\
\text { Fabric }\end{array}$ \\
\hline Mass Polarization & + & - (isotropic) \\
\hline Opal-CT & ++ & +++ \\
\hline Clay Minerals and & & \\
\hline X-ray amorphous & ++ & + \\
\hline Pigmentation & ++ & - \\
\hline Radiolarians & + & +++ \\
\hline Original Porosity & + & ++ \\
\hline Lamination & ++ & + \\
\hline
\end{tabular}

voids of fossils (up to 5 per cent). Quartz has not been observed to replace the opal-CT matrix of the porcellanites.

\section{Preservation of Radiolarians}

The abundance, type, and state of preservation of opaline skeletons in silicified rocks is a very important criterion for all studies concerned with the origin, diagenetic mobilization, and local reprecipitation of silica.

At Sites 386 and 387, the optically determined $\mathrm{SiO}_{2}$ phases of the siliceous skeletons are positively corre- lated with the degree of diagenetic maturation of the associated silicified sediments. Above the mid-Eocene porcellanites, only well-preserved opaline skeletons (opal-A) were observed (upper Eocene). The boundary between radiolarians and diatoms preserved as opal-A and as opal-CT coincides with the uppermost porcellanites of each site. The opal-CT stage is characterized by marked deterioration of preservation of the skeletons. Apart from the quartz-replaced sponge spicules (Site 387), diagenetic quartz occurs only as cement-filling radiolarians and foraminifers. With increasing burial depth and age, however, the radiolarian skeletons themselves are also transformed into quartz. This holds true also for the Cretaceous radiolarians at Site 386 , where quartz cherts are missing.

In the porcellanites, the preservation of opal-CT-replaced radiolarians varies considerably, even within the area of a single thin section. Sometimes the dense area of the opal-CT matrix contains skeletons better preserved than the originally more porous parts with lepisphere-type fabric.

On SEM photos of the skeletal surface (Plate 1, Figures 3,6 ) one can observe the typical groups of opalCT blades, which are intergrown according to specific twinning laws of tridymite (Flörke et al., 1976). These opal-CT blades represent only an overgrowth, but because no appreciable opal-A contents could be determined by XRD, in situ replacement of the underlying skeletons by opal-CT is highly probable. 
According to the intensity of opal-CT growth, the cavities of radiolarians are either lined with marginal lepispheres or completely filled by structureless opalCT casts. By analogy with carbonate diagenesis, these marginal blades, hemispheres, and lepisphere form an early-diagenetic silica "cement A." The remaining voids are filled by later-diagenetic cement generations (e.g., zeolites, quartz).

\section{Silicified Turbidites}

Within the rhythmically bedded lower to middle Eocene sedimentary units of Site 387, a few of the interbedded turbidites (basal subunit $\alpha$ ) are silicified (Table 2, Figure 2:5). The sand layers contain up to 22 per cent sponge spicules, up to 25 per cent terrigenous coarse silt to fine sand, and small but characteristic admixtures (less than 1 per cent) of detrital glauconite and fish remains. Apparently, a micritic matrix was present in these arenites before silicification, so that the original carbonate content (micrite + foraminifers) may have been more than 50 per cent.

Because of the lack of relief in the highly cemented arenites under the SEM, the opal-CT matrix was etched using $\mathrm{H}_{2} \mathrm{SiF}_{6}$ (von Rad et al., 1978), which exposed the quartz-replaced sponge spicules without altering their surface structure (Plate 3, Figures 5-6). By decalcification with $\mathrm{HCl}$, fine details of the silicification of foraminifers can be demonstrated (Plate 3, Figures $1,4)$.

Quantitatively, the most important diagenetic processes in these silicified arenites are (1) the formation of an opal-CT "cement," and (2) transformation of the primary opal-A of the sponge spicules into quartz.

1) Genetically, the opal-CT is both an intra-micrite cement and a replacement of the original nannomicritic matrix. This is demonstrated by the presence of scattered fine-grained relict carbonate (Plate 3, Figure 1) and by the unoriented lepisphere-type fabric (Table 3; Plate 3, Figure 2).

2) Most of the diagenetic quartz of the arenites is concentrated in sponge spicules. Although the spicules and their interiors have been mostly replaced by quartz, the central canal can be clearly recognized under crossed nicols. In part, the canals are filled with opal-CT; lepispheres can rarely be observed in the walls. SEM photos of those spicules which have been exposed by $\mathrm{H}_{2} \mathrm{SiF}_{6}$ show globulose to faintly bladed surface structures (Plate 3, Figure 6) resembling the surfaces of quartz-replaced lepispheres (Figure 4), and indicating an opal-CT precursor stage.

Only a small proportion of the diagenetic quartz in these arenites is represented by a late-generation genuine cavity-filling cement (e.g., in foraminifer chambers) or by partly quartz-replaced calcite foraminifer tests (Plate 3, Figure 3). On the other hand, foraminifer chambers are often filled with massive opal-CT, and opal-CT-filled wall pores form the connections to the opal-CT matrix outside the foraminifer (Plate 3, Figure $4)$.

\section{Nodular Porcellanites (carbonate environment)}

This type of porcellanite occurs in association with the marly nannofossil oozes and foraminifer nannofossil chalks ( 50 to 82 per cent $\mathrm{CaCO}_{3}$ ) of Site 384 . Despite their age (50-55 m.y.), they are relatively poorly consolidated. The high porosities (68 to 76 per cent) favor the migration of pore solutions and the associated mechanisms of silicification.

The Paleocene to middle Eocene calcareous oozes contain a small ( 3 to 10 per cent) but well-preserved assemblage of radiolarians. In the porcellanitic zone, scattered whitish patches with 20 per cent clay and 12 to 15 per cent radiolarians are reported (see Site 384 Report, this volume). Within the rocks we investigated, only traces of siliceous microfossils were noted.

The calcareous porcellanites of Site 384 show a gradual transition from pure chalk via weakly silicified (Figure 2:1a) to opal-CT-rich (up to 80 per cent) zones. This contrasts with the sharp porcellanite/chalk boundaries which are so typical of nodular porcellanites and cherts. In detail, opal-CT impregnates the calcareous matrix in a diffuse manner (Figure 2:1b; Plate 2, Figures 1-3), partly cementing, partly replacing microcrystalline calcite. ${ }^{2}$ The micrite fillings of foraminifer chambers are significantly more replaced or cemented by opal-CT than the surrounding matrix (Plate 2, Figure 1).

The incipient filling of open cavities is characterized by isolated opal-CT blades (about $1 \mu \mathrm{m}$ long and 0.1 to $0.2 \mu \mathrm{m}$ thick; Plate 2, Figure 4) developing into embryonic and finally into complete well-bladed lepispheres (Flörke et al., 1976, fig. 1). Progressive cementation of the interstices between the interpenetrating blades results in a dense opal-CT matrix or mold of the former fossil (Plate 2, Figure 3). In places, the matrix of these rocks still contains a lepisphere-type fabric (Table 3 ). Within the investigated calcareous porcellanites, the proportion of diagenetic quartz is insignificant (Table 2). Quartz is restricted to foraminifer chambers and walls in rocks containing a high proportion (more than 50 per cent) of opal-CT.

\section{LITHOFACIES OF LOWER CRETACEOUS QUARTZ CHERTS}

The host rocks of the Lower Cretaceous (late Berriasian to middle Valanginian) quartz cherts are pelagic micritic limestones, marlstones, and chalks. In our samples there are up to 10 per cent dissolved microfossils, apparently ghosts and partly pyritized radiolarians.

The 130-m.y.-old cherts which have partly replaced these carbonate rocks are essentially free of opal-CT. However, the fossil ghosts definitely contain quartz-re-

2 In thin sections, the opal-CT proportion can only be distinguished from microcrystalline calcite at 400 -fold magnification, with additional illumination with the condensor front lens, and with the gypsum plate inserted (Plate 2, Figures 1,2). Under the SEM the degree of silicification of $\mathrm{HCl}$-treated specimens can be well recognized (Plate 2, Figures 5, 6). 
placed lepispheres (Figure 4). Under transmitted light, these replaced lepispheres consist of fibro-radiated quartz or a few granular crystals. In SEM photos, these quartz lepispheres can be recognized only if the remaining pore space has not been filled by quartz.

In SEM photos the broken surface of the chert (Figure 3) has a globular appearance (diameter of spherules: 0.2 to $0.5 \mu \mathrm{m}$ ). Since a similar ultrastructure was also observed in the dense opal-CT matrix of porcellanites, an optical analysis always supplemented the SEM investigations.

The degree of pigmentation appears to be negatively correlated with the "maturity" of a chert (Figure $2: 2 \mathrm{a}$ ); i.e., a highly transparent, homogeneous quartz chert is the end product of chertification of more pigmented precursors. Highly pigmented patches in the chert of one sample (from Section 387-47-1) contain 3 per cent relict carbonate particles (less than $4 \mu \mathrm{m}$ in diameter); the individual quartz grains within the cloudy matrix can hardly be distinguished.

In one sample, the transition from the micritic limestone to the quartz chert can be studied (Figure 2:2b): two sharp boundaries separate a calcareous chert zone from a carbonate-free chert and from an unsilicified micrite. It is remarkable that radiolarian ghosts are only present in both cherty zones. Apparently, these fossils have caused locally increased permeability of

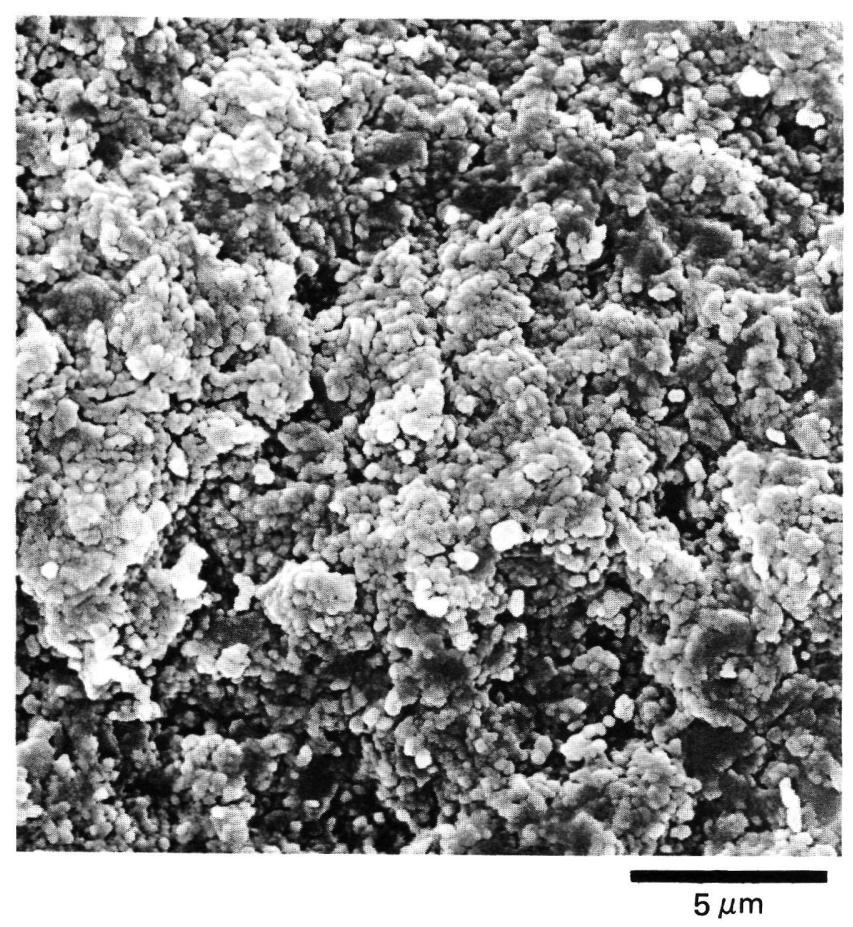

Figure 3. Scanning electron photomicrograph of globular quartz chert (Sample 387-46-1, 97-99 cm; middle Valanginian, SEM 797/1, $4000 \times)$. The size of the spherules or globules (0.2 to $0.5 \mu \mathrm{m})$ is much smaller than the smallest crystallite size resolved by optical microscopy $(\sim 10 \mu \mathrm{m})$. A similar ultrastructure was observed also in the opal-CT matrix of porcellanites.

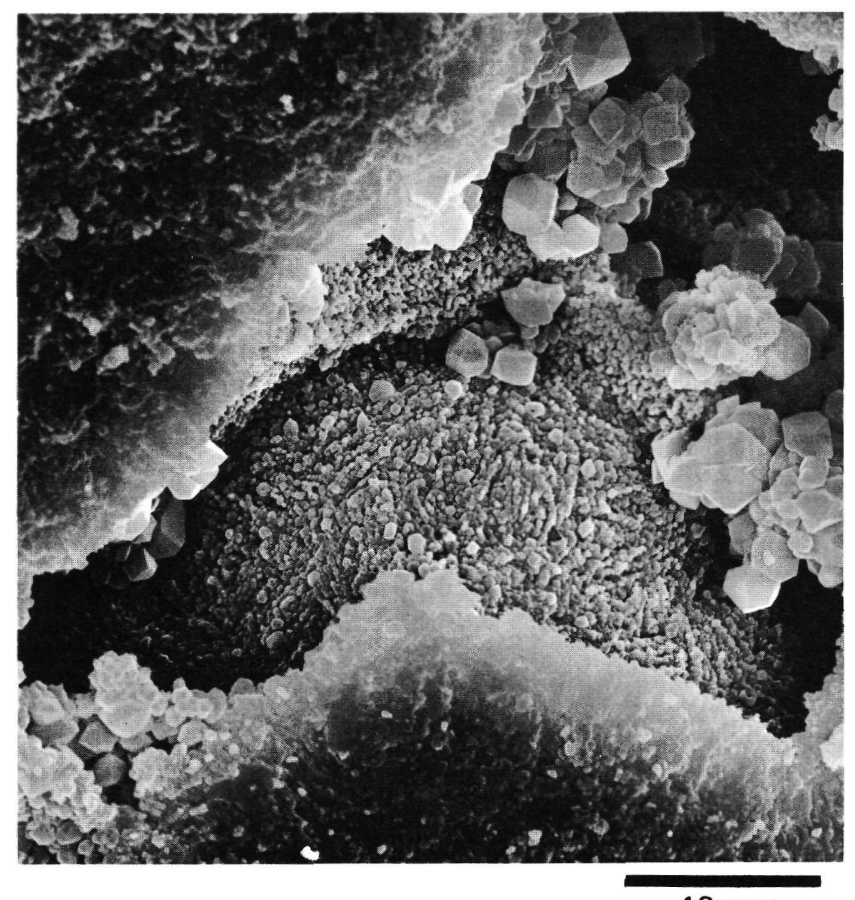

$10 \mu \mathrm{m}$

Figure 4. SEM photo of quartz chert, with dense quartz matrix (outside cavity) and quartz-replaced lepispheres (with relict structure of interpenetrating former opal-CT blades!) in open cavity. Note also tiny euhedral quartz crystals as last cavity filling. (Sample 387-47-1, 83-85 cm; lower Valanginian; SEM 797/5, 2000 X).

these micro-environments, favoring their infiltration by silica-precipitating pore waters.

\section{ORIGINAL SEDIMENTS AND SILICA DIAGENESIS}

Facies of Porcellanite-Producing Sediments and the Origin of Horizon $A$

The lower to middle Eocene porcellanites (and cherts) of western North Atlantic Basin Sites 6 and 7 (Leg 1); 8, 9, and $10(\operatorname{Leg} 2) ; 106(\operatorname{Leg} 11)$; and 384 through 387 (Leg 43); and the paleogeographically corresponding rocks of the eastern Sites 12 (Leg 2); 13 (Leg 3); 140 (Leg 14); and 366 through 370 (Leg 41) have a surprisingly synchronous age. They are, however, associated with highly heterogeneous lithofacies, ranging from clayey abyssal sediments deposited below the CCD to calcareous oozes (e.g., 384); from slowly deposited eupelagic to rapidly accumulated hemipelagic sediments in seamount flank, rise, and slope settings with a strong influx of turbidites (e.g., 386 and 387). This means that no tendency could be observed for preferred silicification of a given lithofacies type.

In our brief discussion of the origin of the famous Horizon $A$ reflector sequence, we shall only consider North Atlantic sites where Eocene porcellanites have been cored, and omit those occurrences where this reflector has been identified as an erosional unconformity with a lower to middle Cretaceous/mid-Cenozoic hia- 


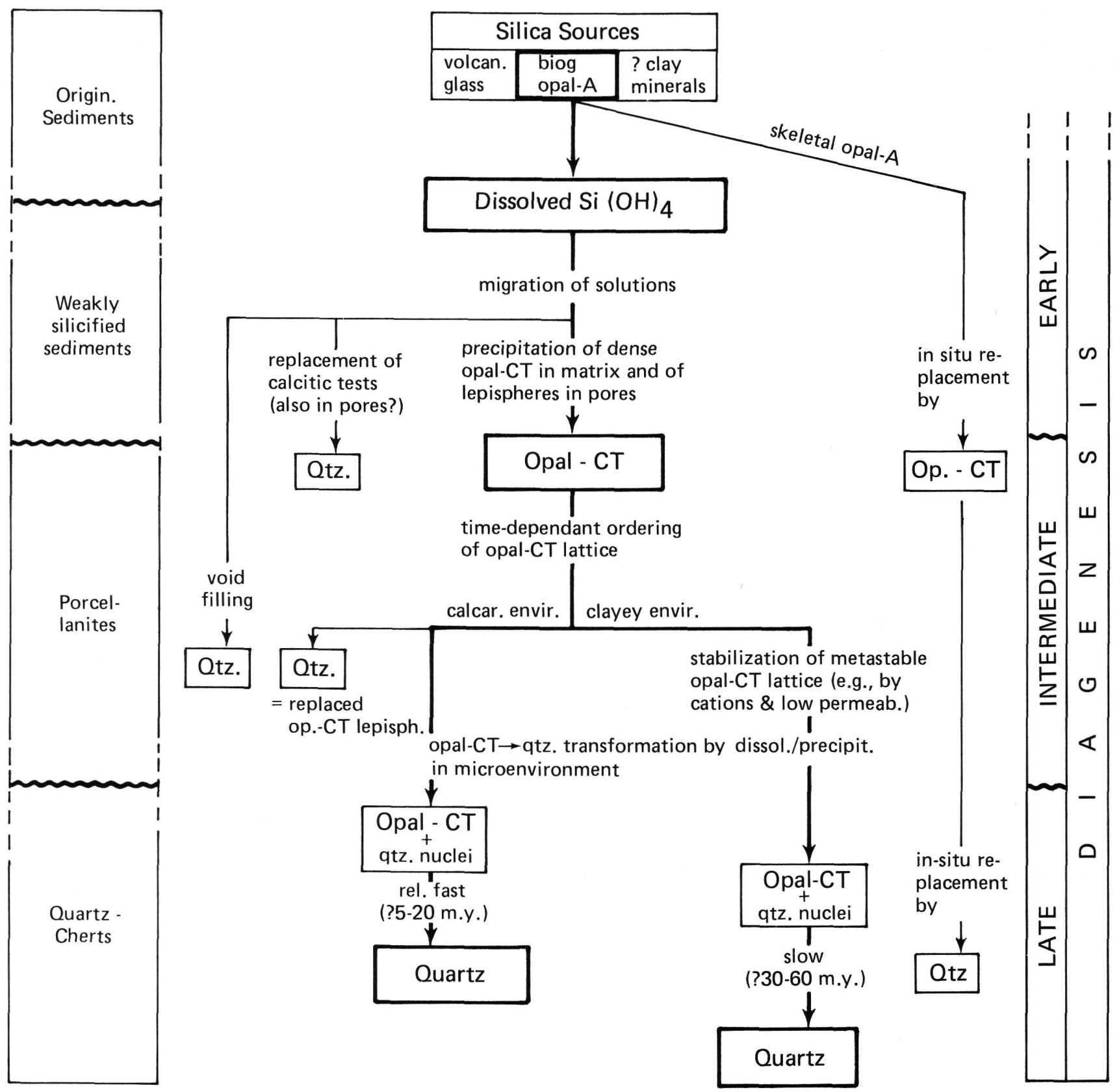

Figure 5. Schematic diagram showing transformation and diagenetic processes between opal-A, opal-CT, and diagenetic quartz (modified from von Rad et al., 1978).

tus (e.g., Sites 101 and 105; Berggren and Hollister, 1974). Because of the positive correlation between the frequency and vertical distribution ( 8 to $150 \mathrm{~m}$ ) of Eocene porcellanites with sediment accumulation rates, a causal relationship between periods of erosion or nondeposition and the formation of "cherts," as proposed for Site 384 , is very unlikely.

\section{Volcanic Origin}

On the basis of the authigenic volcanic mineral association opal-CT-montmorillonite-clinoptilolite, Gibson and Towe (1971) and Mattson and Pessagno (1971) have suggested that the silica of the Eocene "cherts" was originally derived from diagenetic alteration of widespread vitreous ash layers that are thought to be synchronous with volcanic rocks in the Caribbean. Although volcanogenic sediments are abundant at Sites 382,385 , and 386 , they are never associated with porcellanites or cherts (Figure 1). Thus, a volcanic silica source is rejected for the Leg 43 porcellanites.

\section{Biogenic Origin Resulting From Increased Fertility}

All the calcareous, clayey, or turbiditic porcellanitebearing sediments contain siliceous fossils, although the contents show wide facies-dependent fluctuations. This means that a biogenic silica source is highly probable. 
The surprising concentration of silicified rocks in the lower to middle Eocene is often explained by widespread siliceous plankton blooms consequent to a sudden increase of fertility in an extended equatorial belt during the early to middle Eocene. This may have been caused by the initiation of vigorous circulation after the opening of the North Atlantic and the formation of cold North Atlantic bottom water 50 to 60 m.y. ago (Berggren and Hollister, 1974; Weaver and Wise, 1974). Increased plankton productivity can be also attributed to an unrestricted nutrient and silica-rich equatorial surface and subsurface current flowing, during Cretaceous and early Paleogene times, from the Pacific via an open Isthmus of Panama into the Caribbean and the North Atlantic Basin (Ramsay, 1973).

\section{Biogenic Origin Attributed to Enhanced Preservation}

According to Berger (1974) and Fischer and Arthur (1977), silica deposition and retention is favored not only by high supply but also by high sediment accumulation rates, high organic carbon contents, and silicarich or silica-saturated bottom waters. During thalassocratic or polytaxic times (such as the Eocene), warm equable climates with low vertical and latitudinal temperature gradients produced a sluggish deep circulation with silica-saturated and oxygen-depleted bottom waters (Fischer and Arthur, 1977). The flooded shelves tied up much carbonate, thus raising the CCD and producing a silica-rich ocean.

In addition to depositional or preservational aspects, concentration by diagenetic mechanisms also has to be considered, to explain the fact that only the lower to middle Eocene sediments have developed into porcellanites, whereas upper Eocene to Oligocene and Cretaceous radiolarian-rich sediments have not been silicified. Further studies on the physical properties, lithofacies, and preservation of siliceous fossils are necessary to reach a better understanding of the potential of siliceous sediments for future diagenetic change during all stages between deposition and deep burial ("diagenetic potential" of Schlanger and Douglas, 1974).

\section{Early Diagenetic Formation of Porcellanites}

All the Eocene silicified rocks from Leg 43 are genuine porcellanites that have not yet matured into quartz cherts (Table 1). In agreement with our results from previous legs, opal-CT is always the first silica phase during silicification (Figure 5), irrespective of the associated lithofacies. Apparently, this is a demonstration of Ostwald's rule, which states that an unstable (less energetic) phase usually passes through one or more intermediate phases before transforming structurally into a truly stable, high-energy phase (quartz). Under low-energy conditions the metastable opal-CT will usually form first and persist for geologically significant times (Jones and Segnit, 1971).

Within the carbonates (Site 384), the earliest opalCT crystallites always form on top of a first calcite cement (syntaxial enlargement of biogenic particles; Plate 2, Figure 4). Thus, this initial silicification is al- ready a second phase during early diagenesis. The maximum opal-CT content appears to occur in highporosity zones of the associated oozes and chalks. If the replacement process does not start before the pore space has been completely cemented, this may indicate that the early-diagenetic opal-CT in those carbonate rocks is mainly a cement. The calcareous porcellanites (Site 384) show gradual transitions into weakly silicified chalks. This contrasts with Eocene porcellanites from the eastern North Atlantic (Site 366), which are associated with more consolidated chalks and limestones, and occur as discrete lenses or nodules with distinct boundaries. Possibly the patchy or diffuse silicification within the Leg 43 sediments is caused by the higher permeability and concomitantly less restricted conditions of crystallization.

Within the silicified turbidites, the opal-CT matrix which still contains some fine-grained relict carbonate has either a dense or lepisphere-type fabric (Plate 3, Figure 2). Since no zoned opal-CT cement A was observed, an originally porous calcilutitic matrix can be inferred from the fabric. Because of a high nucleation rate, abundant lepispheres filled the pore space, before most of the micritic sediment was replaced.

Some of the clayey (bedded) porcellanites are characterized by aggregate polarization; in the Leg 43 specimens investigated, this optical phenomenon occurs only in zones with a dense opal-CT matrix, and never in zones with a lepisphere-type fabric (Table 3). The aggregate polarization results from the oriented growth of authigenic opal-CT and silicates (e.g., palygorskite) parallel to the bedding plane and is influenced by the compaction-related fabric of the associated phyllosilicates. It is therefore not surprising that zones with randomly oriented opal-CT lepispheres do not show this phenomenon.

\section{Formation of Quartz Prior to Chertification}

Prior to the late-diagenetic opal-CT $\rightarrow$ quartz transformation, quantitatively subordinate formation of quartz can be observed (Figure 5). Genetically, this quartz occurs as: (a) replacement of calcitic foraminifer tests (Keene, 1975); (b) latest cement generation filling larger cavities (with small cavities already closed by opal-CT); (c) in situ replacement of sponge spicules after an opal-CT precursor phase.

Apparently, the precipitation of cavity-filling quartz (b) represents the beginning of the chert stage and indicates a change in the pore-water chemistry. Because of dissolution of skeletal opal, the silica concentration increases at a relatively fast rate and opal-CT is precipitated (Kastner and Keene, 1975). After the dissolution rates of siliceous skeletons decreased and most of the dissolved silica was used up to form opal-CT, quartz cement was precipitated. Since quartz formed only in a few of the remaining larger cavities within the porcellanites, the originally silicified areas were not extended. Compared with the late-diagenetic recrystallization of opal-CT into quartz, the formation of these quartz phases (a-c) appears to take less activation energy; possibly the breaking of Si-O bonds within the opal-CT 
structure demands longer time intervals (Heath and Moberly, 1971; Jones and Segnit, 1972).

\section{Late-Diagenetic Transformation of Porcellanites into Quartz Cherts}

The opal-CT $\rightarrow$ quartz transformation of the matrix which follows the quartz cement phase does not start simultaneously in all porcellanitic areas. Certain particles and microenvironments can be seen already to possess a diagenetic advantage; a premature quartzification takes place in: (1) centers of concentrically zoned porcellanite nodules (Leg 41); (2) opal-CT fillings of foraminifer chambers bordering on quartz cement or quart-replaced tests ( $\operatorname{Leg} 41,43) ;(3)$ sponge spicules (Leg 43).

Apparently the opal-CT $\rightarrow$ quartz transformation is a time- and temperature-dependent maturation process (von Rad et al., 1978). Since the centers of the chert nodules (1) seem to be older than their outer rims, they are the first areas to be quartzified. Our observations do not confirm the primary formation of quartz chert cores within porcellanite nodules (Millot, 1970; Lancelot, 1973; Kastner and Keene, 1975).

Within fossils (2), the recrystallization may be catalyzed by quartz from the immediate vicinity. It is possible that the sponge spicules (3) are diagenetically less stable and are transformed from opal-A to opal-CT and further into quartz earlier than radiolarians.

Apart from the above-mentioned exceptions $(2,3)$, the opal-CT $\rightarrow$ quartz transformation has not yet started in the Eocene porcellanites of Leg 43. However, within the quartz cherts of the Lower Cretaceous limestones, which certainly had passed through a porcellanite stage, this recrystallization is already completed.

Possibly owing to the shallow burial depth $(95 \mathrm{~m})$, the Eocene calcareous porcellanites (especially the foraminifer tests) are less quartzified than the corresponding rocks from Leg 41: at Site 366 the first quartzose microlenses occur at a sediment depth of 520 meters, and the intensity of quartzification increases discontinuously down to a depth of 800 meters. These observations and the progressive diagenetic ordering of the opal-CT structure (von Rad et al., 1978) suggest a positive relationship between the rate of this transformation and depth of burial (i.e., temperature) (Ernst and Calvert, 1969; Heath and Moberly, 1971; Murata and Nagata, 1974; Murata and Larson, 1975).

\section{In Situ Transformation of Siliceous Fossils}

The siliceous fossils that have escaped dissolution have been directly replaced by opal-CT (Figure 5; Plate 1, Figures 2,3,6). Apparently, the uppermost porcellanites of Site 386 and 387 mark the boundary between diatoms and radiolarians preserved as opal-A and those preserved as opal-CT. With increasing depth of burial and age the skeletons are finally replaced by quartz.

Only quartz-replaced sponge spicules were observed (Plate 3, Figures 5,6). However, the bladed surface morphology proves that the spicules were first replaced by opal-CT, and this was followed by comparatively early recrystallization into quartz without intervening dissolution steps. In analogy with the two major transformation steps of chert diagenesis, this in situ transformation of siliceous fossils (opal-A $\rightarrow$ opal-CT $\rightarrow$ quartz) is another demonstration of the maturation hypothesis based on Ostwald's rule.

\section{ACKNOWLEDGMENTS}

This study was supported by a grant from the German Research Society (DFG) for the investigation of North Atlantic deep-sea cherts. We are very grateful to Dr. H. Rösch (Hannover) for contributing all quantitative $\mathrm{X}$-ray diffraction analyses (Table 2), and to Mr. E. Knickrehm (Hannover) for his expertise at the Siemens (ETEC) Autoscan electron microscope. We also thank Dr. B. Tucholke (Palisades, N.Y.) and Dr. P. Rothe (Mannheim) for giving us the opportunity to study Leg 43 cherts and Drs. S. E. Calvert (Wormley) and H. Rösch (Hannover) for reviewing and improving the manuscript.

\section{REFERENCES}

Berger, W. H., 1974. Deep-sea sedimentation. In Burk, C. A. and Drake, C. L. (Eds.), The geology of continental margins: New York, Heidelberg, Berlin (Springer), p. 213242.

Bergren, W. H. and Hollister, C. D., 1974. Paleogeography, paleobiography and the history of circulation in the Atlantic Ocean. In Hay, W. W., (Ed.), Studies in paleo-oceanography: Soc. Econ. Paleont. Mineral., Spec. Publ., 20, p. $126-186$.

Calvert, S. E., 1974. Deposition and diagenesis of silica in marine sediments. In Hsü, K. J., and Jenkyns, H. C., (Eds.), Pelagic sediments: on land and under the sea, Spec. Publ. Int. Assoc. Sediment., v. 1, p. 273-299.

Ernst, W. G. and Calvert, S. E., 1969. An experimental study of the recrystallization of porcelanite and its bearing on the origin of some bedded cherts, Am. J. Sci. (Schairer Vol.), v. 267A, p. 114-133.

Fischer, A. G. and Arthur, M. A., 1977. Secular variations in the pelagic realm. In Cook, H. E. and Enos, P. (Eds.), Deep Marine Carbonate Environments: Soc. Econ. Paleont. Mineral., Spec. Publ., 25, p. 19-50.

Flörke, O. W., Hollmann, R., von Rad, U., and Rösch, H., 1976. Intergrowth and twinning in opal-CT lepispheres. Contrib. Mineral. Petrol., v. 58, p. 235-242.

Gibson, T. G. and Towe, K. M., 1971. Eocene volcanism and the origin of Horizon A: Science, v. 172, p. 152-153.

Heath, G. R. and Moberly R., Jr., 1971. Cherts from the Western Pacific, Leg 7, Deep Sea Drilling Project. In Winterer, E. L., Riedel, W. R., et al., Initial Reports of the Deep Sea Drilling Project, v. 7, Part 2: Washington (U. S. Government Printing Office), p. 991-1007.

Jones, J. B. and Segnit, E. R., 1971. The nature of opal, I. Nomenclature and constituent phases, J. Geol. Soc. Australia, v. 18, p. 57-68.

Jones, J. B. and Segnit, E. R., 1972. Genesis of cristobalite and tridymite at low temperatures, J. Geol. Soc. Australia, v. 18 , p. $419-422$.

Kastner, M. and Keene, J. B., 1975. Diagenesis of pelagic siliceous oozes, Ninth Internat. Congr. Sediment., Nice, v. 7, p. 89-99.

Keene, J. B., 1975. Cherts and porcellanites from the North Pacific, Deep Sea Drilling Project Leg 32. In: Larson, R. L., Moberly, R., et al, Initial Reports of the Deep Sea Drilling Project, v. 32: Washington (U. S. Government Printing Office), p. 429-507. 
Lancelot, Y., 1973. Chert and silica diagenesis in sediments from the Central Pacific. In Winterer, E. L., Ewing, J. I., et al., Initial Reports of the Deep Sea Drilling Project, v. 17: Washington (U.S. Government Printing Office), p. 377-506.

Mattson, P. H. and Pessagno, E. A., 1971. Caribbean Eocene volcanism and the extent of Horizon A: Science, v. 174, p. 138-139.

Millot, G., 1970. Geology of clays: New York, Heidelberg, Berlin, (Masson \& Cie, Chapman \& Hall).

Murata, K. J. and Larson, R. R., 1975. Diagenesis of Miocene siliceous shales, Temblor Range, California: J. Res. U.S. Geol. Surv., v. 3, p. 553-566.

Murata, K. J. and Nakata, J. K., 1974. Cristobalitic stage in the diagenesis of diatomaceous shale: Science, v. 18, p. 567.

Ramsay, A. T. S., 1973. A history of organic siliceous sediments in oceans. In Hughes, N. F. (Ed.), Special papers in paleontology: Paleont. Assoc. London: v. 12, p. 199-234.
Schlanger, S. O. and Douglas, R. G., 1974. Pelagic oozechalk-limestone transition and its implications for marine stratigraphy. In Hsü, K. J. and Jenkyns, H. C. (Eds.), Pelagic sediments: on land and under the sea: Spec. Publ. Int. Assoc. Sediment., v. 1, p. 117-148.

von Rad, U. and Rösch, H., 1974. Petrography and diagenesis of deep-sea cherts from the Central Atlantic. In Hsü, K. J. and Jenkyns, H. C. (Eds.), Pelagic sediments: on land and under the sea: Spec. Publ. Int. Assoc. Sediment, v. 1, p. 327-347.

von Rad, U., Riech, V., and Rosch, H., 1978. Silica diagenesis in continental margin sediments off northwest Africa. In Lancelot, Y., Seibold, E., et al., Initial Reports of the Deep Sea Drilling Project, v. 41: Washington (U.S. Government Printing Office), p. 879-906.

Wise, J. W., Jr. and Weaver, F. M., 1974. Chertification of oceanic sediments. In Hsü, K. J. and Jenkyns, H. C. (Eds.), Pelagic sediments: on land and under the sea: Spec. Publ. Int. Assoc. Sediment., v. 1, p. 301-326. 



\section{PLATE 1 \\ Bedded porcellanites (BI): matrix lepispheres; preservation and fillings of siliceous fossils.}

Figure 1 Sample 387-18-1, 87-93 cm (lower Eocene, SEM photo $796 / 7,4000 \times$ ). The matrix is remarkably rich in opal-CT lepispheres, probably because of the relatively high porosity. Those poorly bladed (stubby or spiny) lepispheres were observed only in bedded porcellanites associated with the clayey environment.

Figure 2 Sample 386-30-2, 95-97 cm (? lower Eocene, thin-section photomicrograph 39/21). Bedded porcellanite with poorly (ghosts) to relatively well preserved radiolarians. The original opal-A of the outer skeleton of the large radiolarian (center) has been replaced by opal-CT, whereas the delicate internal skeleton has been completely destroyed. Later, opal-CT and tiny zeolite laths have been precipitated in the free pore space (see Plate 1, Figure 3).

Figure 3 Sample 386-30-2, 95-97 cm (? lower Eocene, SEM 787/2, 420 $\times$ ). SEM photo corresponding to Plate 1, Figure 2. Opal-CT replaced radiolarian skeleton, showing bladed structure on internal wall surface. By this diagenetic process the wall thickness of the skeleton was increased and the diameter of the wall pores decreased. Additional lepispheres and authigenic zeolites grow into open cavity (cement A)

The dense (structureless) part of the wall has probably also experienced an early diagenetic in-situ transformation of opal-A into opal-CT.

Figure $4 \quad$ (Same as Figure 3, SEM 787/4, 720 $\times$ ). This SEM photo shows either the same process as described in Plate 1, Figure 3 (with more lepispheres filling the cavity of a fossil) or the opalCT filling of a radiolarian ghost (with the original skeleton completely dissolved and not replaced by opal-CT). In the final diagenetic stage of porcellanite formation, the radiolarians can be transformed into completely structureless opal-CT spheres.

Figure 5 Sample 386-29-2, 95-97 cm (? middle Eocene, SEM $787 / 8,1100 \times$ ). Euhedral zeolite $(?$ clinoptilolite) crystals and large (in part composite) opal-CT lepispheres in the cavity of a radiolarian. The zeolite is always the last cavityfilling generation (penetrates or grows around lepispheres; see also small molds on crystal surface). Broken lepisphere (lower right) shows dense structureless interior.

Figure 6 Sample $387-15, \mathrm{CC}, 3-5 \mathrm{~cm}$ (? middle to ? lower Eocene, SEM 796/6, $3000 \times$ ). Radiolarian spine replaced by opal-CT and partly filled by lepispheres and ? zeolite (as in Plate 1, Figure 3). 
PLATE 1
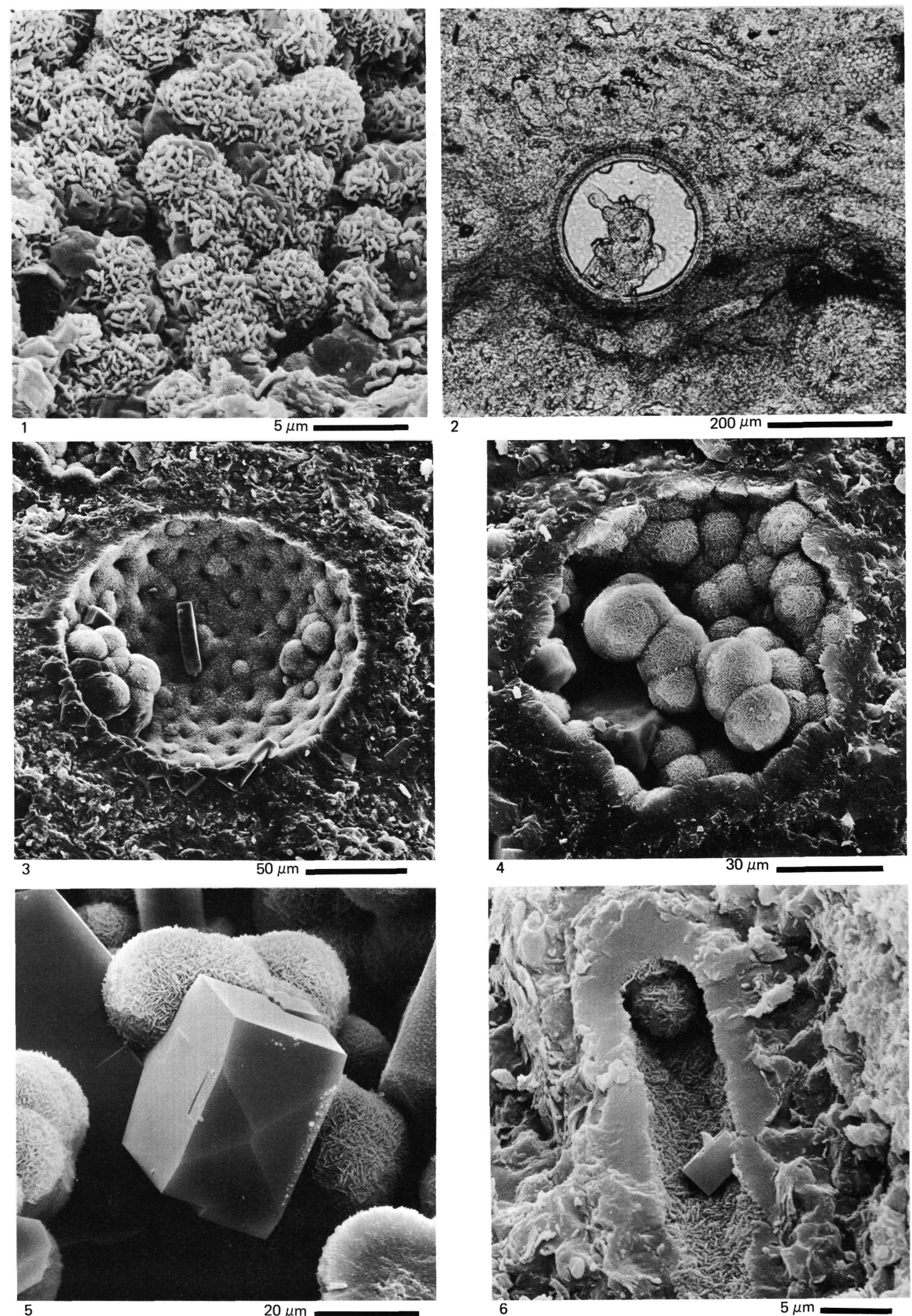
PLATE 2

Thin section and SEM photomicrographs of nodular porcellanites (B II).

Figure 1 Sample 384-5-3, $129 \mathrm{~cm}$ (lower Eocene, 39/11, crossed nicols). Calcareous porcellanite with well-preserved calcitic foraminifers and about 20 per cent calcite within the matrix. Note that the original micrite within foraminifer chambers is much more replaced by opal-CT than the carbonate in the surrounding matrix.

Figure 2 Sample 384-5, CC, 11-14 cm (lower Eocene, $40 / 12$, crossed nicols, gypsum plate inserted). Detail of matrix in calcareous porcellanite (Figure 1). Light-colored carbonate particles (nannofossils, foraminifer remains, etc.) floating in (almost isotropic) opal-CT matrix (see also Plate 2, Figure 3).

Figure 3 Sample 384-5, CC, 14-22 cm (lower Eocene, SEM 785/5, $2000 \times$ ). Matrix ultrastructure of calcareous porcellanite with well-preserved coccoliths and opal-CT mold of foraminifer (center), showing negatives and prisms of euhedral (recrystallized) calcite crystals of chamber wall.

Figure 4 Sample 384-5-3, $129 \mathrm{~cm}$ (lower Eocene, SEM $794 / 6,10,000 \times$ ). A few isolated tiny opal-CT blades with ragged edges growing on earliestdiagenetic calcitic cement within a foraminifer chamber. This is a precursor stage of lepisphere formation (Flörke et al., 1976).

Figure 5 Sample 384-5, CC, 14-22 cm (lower Eocene, $\mathrm{HCl}$ residue, SEM 797/11, $4000 \times$ ). Decalcified porcellanite (calcitic foraminifer wall and coccoliths dissolved) now consisting only of opal-CT. Opal-CT is structureless in dense matrix, but bladed (in part embryonic lepispheres) within fossil cavity (unobstructed growth).

Figure 6 Sample 384-5, CC, 1-6 cm (lower Eocene, $\mathrm{HCl}$ residue, SEM 795/6, $4000 \times$ ). Opal-CT residue of HCl-treated, weakly silicified chalk shows well-bladed structure in open cavities and imperfect crystallites in the matrix (growth obstructed by calcite). Note constancy of angles of interpenetrating crystal blades. 
PLATE 2
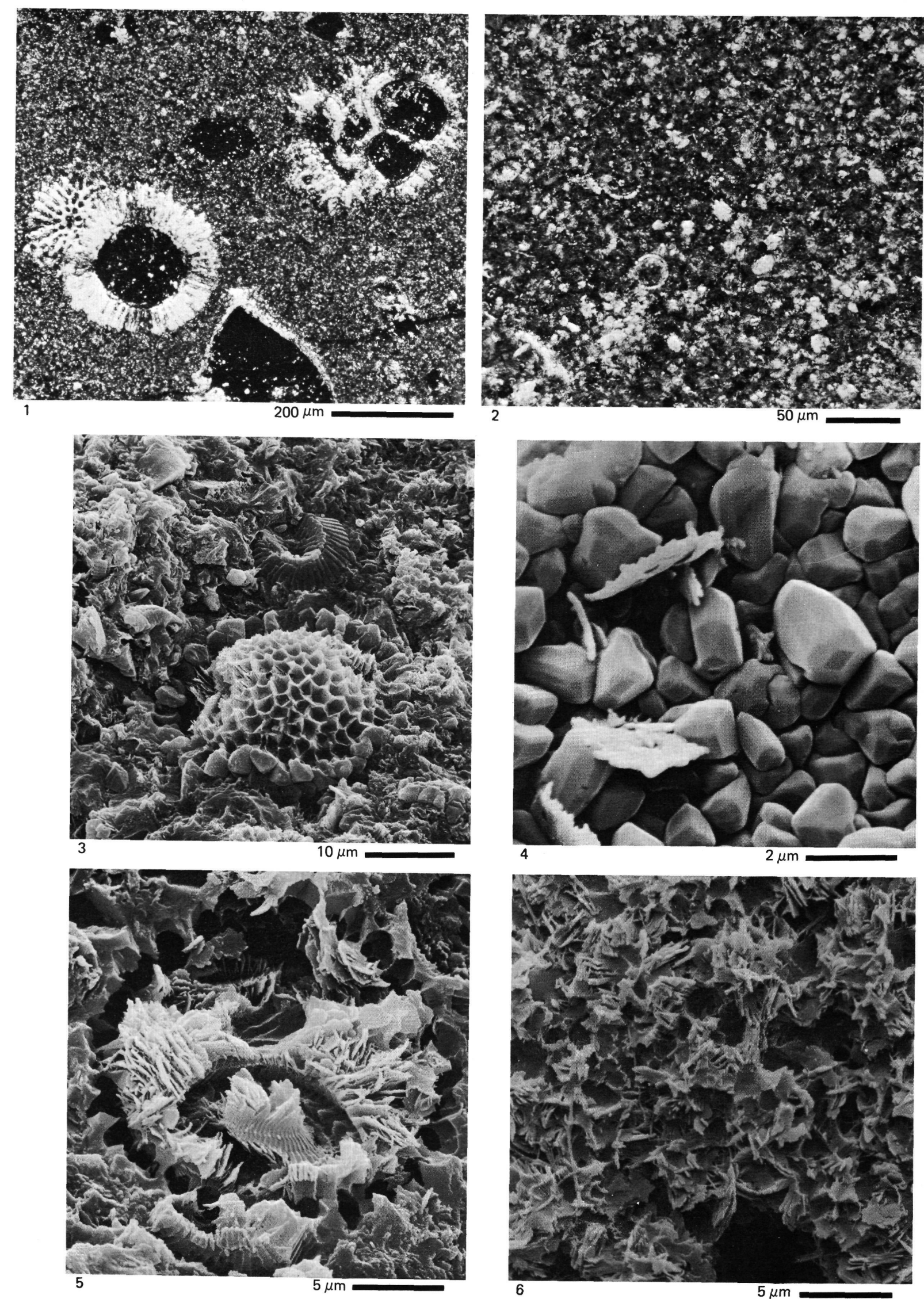
PLATE 3

Opal-CT-cemented turbiditic arenites (B III) and their fossils.

Figures 1-6 Sample 387-17-2, 56-58 cm (? lower Eocene).

1. (HCl-treated, SEM 791/4, $400 \times$ ). Decalcified foraminifer and spiculitic arenite with opal-CT cement (grains with smooth surfaces $=$ terrigenous quartz, rough surface $=$ opal-CT cement with coccolith molds). Opal-CT cast of benthic foraminifer (?Gümbelitria sp.) is in center. Note that many of the very fine pores (less than $2 \mu \mathrm{m}$ ) of foraminifer chamber walls are now filled by acicular opal-CT!

2. This thin-section photomicrograph shows that the apparently dense opal-CT matrix (between foraminifers and quartz grains) consists actually of minute lepispheres (diameter 5 to $15 \mu \mathrm{m}$ ). This opal-CT represents partly a primary void-filling cement, partly it replaces the micritic calcite originally deposited between clastic grains.

3. Benthic foraminifer (Nodosaria sp.) with test wall preserved as calcite, whereas quartz has replaced the septa (apertures also preserved). Interior of chambers is filled by diagenetic quartz and a few opal-CT lepispheres.

4. (SEM 791/6, HCl-treated, $800 \times$ ): detail of planktonic foraminifer within opal-CT cemented arenite. Chamber filling, wall pores (diagenetically thickened!), and surrounding matrix consist of "massive" opal-CT. Compare pore diameter of central foraminifer ( 4 to $8 \mu \mathrm{m}$ ) with that of small (? benthic) foraminifer ( 1 to $2 \mu \mathrm{m}$ ) at upper right.

5. (SEM $787 / 12,40 \times)$. By an extended $(3$ hours) treatment of the calcarenite with $\mathrm{H}_{2} \mathrm{SiF}_{6}$, the quartz-replaced sponge spicules and terrigenous quartzes are concentrated on the specimen surface, whereas the opalCT matrix has been selectively dissolved (except for spongy relicts).

6. (SEM 788/8, also $\mathrm{H}_{2} \mathrm{SiF}_{6}$-treated, $2000 \times$ ). The surface structures (characteristic interpenetration of crystallites) and the preservation of the axial canal of this quartz-replaced sponge spicule suggest the following steps of transformation: (1) early-diagenetic in situ replacement of the original skeletal opal-A by opal-CT, (2) later: in situ replacement of bladed opal-CT by quartz (both processes without a complete dissolution step and without destroying major structures of the original spicule). 
Plate 3

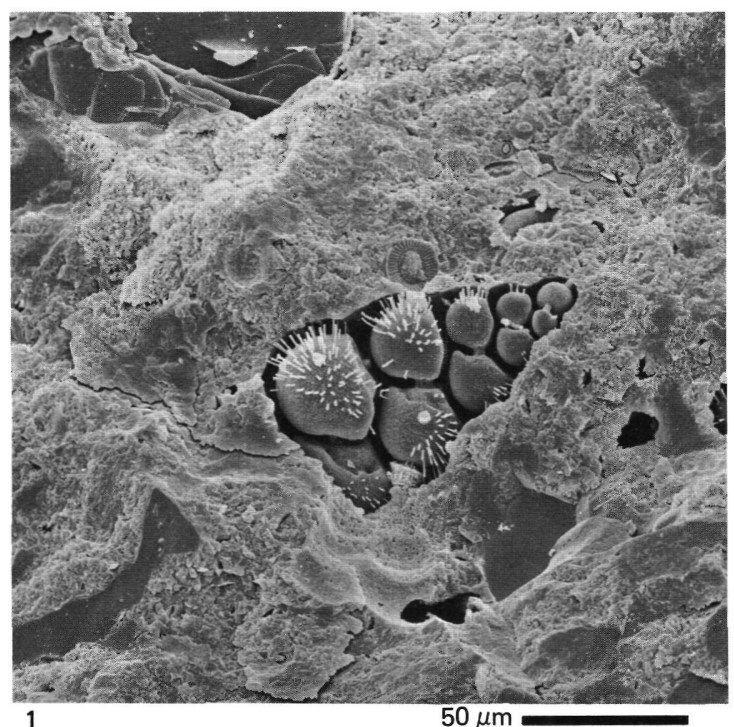

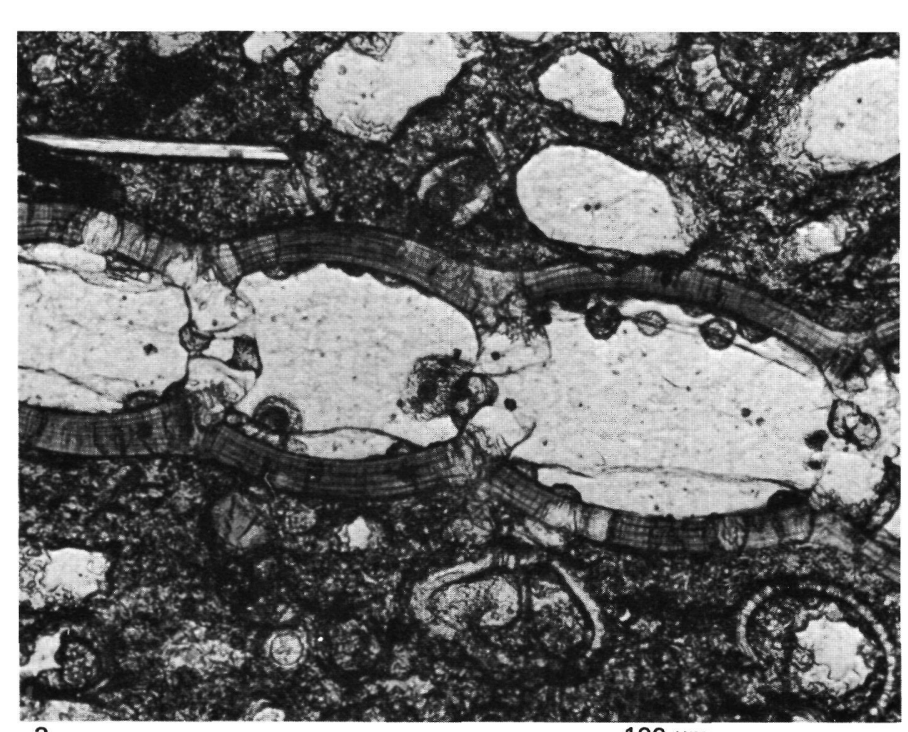

3
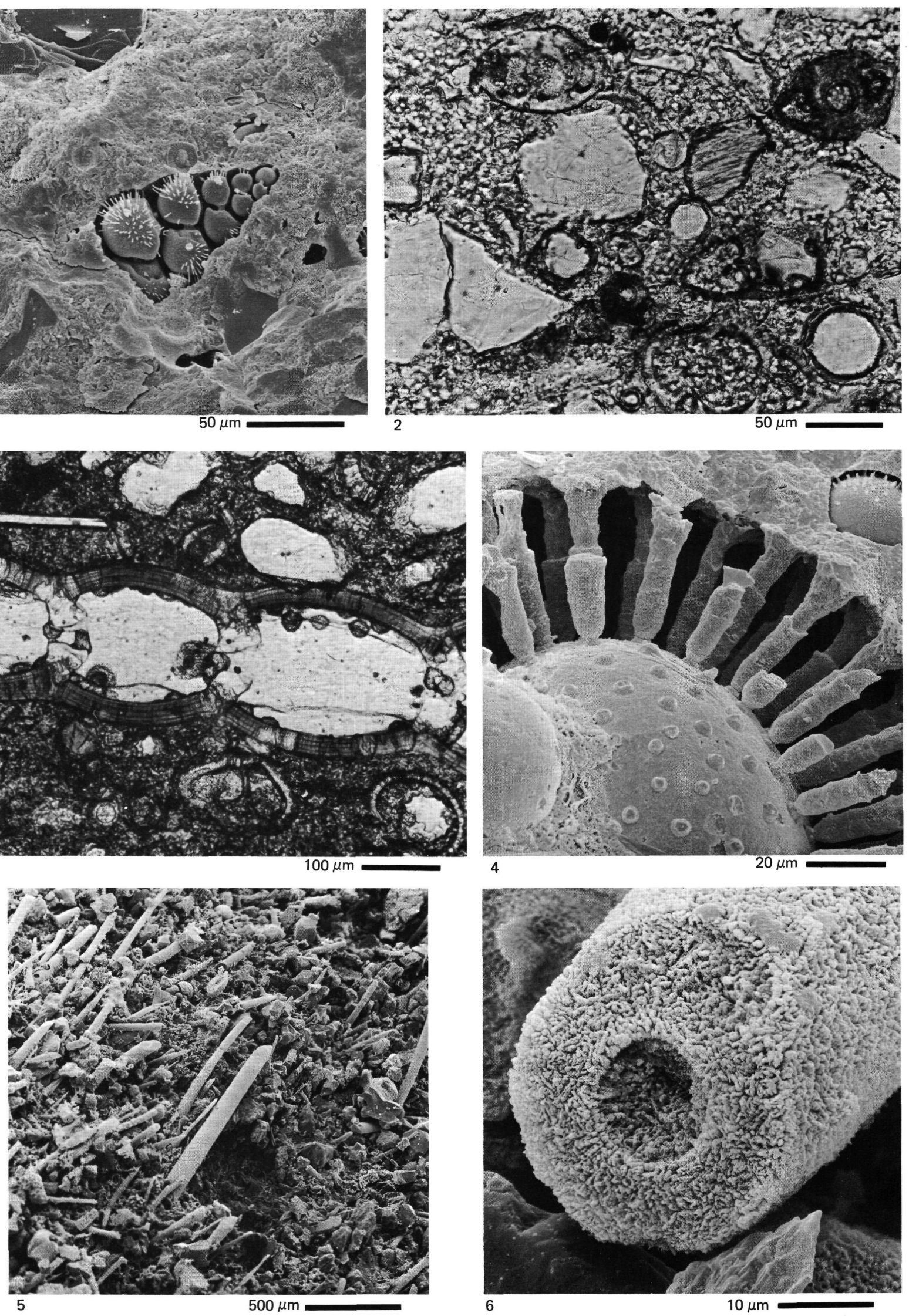